\title{
Bank Dividend Policy and Degree of Total Leverage
}

\author{
Dung Viet TRAN*
}

Received: December 6, 2019 Revised: December 18, 2019 Accepted: December 28, 2019

\begin{abstract}
We provide one of the first investigation on the impact of the degree of total leverage to the dividend policy of bank. We use a large sample of US bank holding companies from 2000:Q1 to 2017:Q4 to shed light our research question. Our empirical analysis provides consistent evidence that banks with high degree of total leverage (i.e. banks with a relatively high fixed-to-variables costs) are less likely to pay dividends, and they spend a lower fraction of incomes to pay back shareholders, suggesting a higher conservatism in dividend policy of banks subject to high degree of total leverage. The evidence remains unchanged with alternative econometric approaches, alternative measures of dividend policy and degree of total leverage. We further document that this higher conservatism is strengthened for a sample of banks with low franchise value during the financial crises. Our result suggests that the conservatism in dividend policy of banks with high degree of total leverage seems to be related to the precautionary motives aimed at preserving corporate resources under financial distress. Our study contributes to the literature of cost structure and dividend policy by pointing out that the impacts of the degree of fixed-to-variable expenses to dividend policy are extended to the case of banks.
\end{abstract}

Keywords: Banks, Dividends, Total Leverage, Vietnam.

JEL Classification Codes: G21, G28

\section{Introduction}

Dividend policy is one of key topics of financial economic literature. Since the seminal works of Miller and Modigliani (1961) on the irrelevance of dividends for firm's value in a context of perfect capital markets with rational investors, there is an extensive literature related to dividends puzzle. Major theories of dividends are signaling, agency, tax preference and clientele effects, catering and firms' life cycle theories. See e.g. Allen and Michaely (2003), Farre-Mensa, Michaely, and Schmalz (2014) for extensive review of seminal contributions in the dividend policy literature. In the aftermath of the financial crisis, dividends attract greater attention of scholars, investors, and especially banking regulators. Regulators impose more restrictions on dividends since dividend payments increase

*First Author and Corresponding Author. Lecturer in Finance, International School of Business, Banking University Ho Chi Minh City, Vietnam. [Postal Address: 36 Ton That Dam Street, District 1, Ho Chi Minh City, 700000, Vietnam] Tel: +84 989808777

Email: dungtv@buh.edu.vn

๑) Copyright: Korean Distribution Science Association (KODISA)

This is an Open Access article distributed under the terms of the Creative Commons Attribution NonCommercial License (https://creativecommons.org/licenses/by-nc/4.0/) which permits unrestricted noncommercial use, distribution, and reproduction in any medium, provided the original work is properly cited. leverage, reduce capital which is considered as a lossabsorbing cushion (Committee Basel, 2010; FRB, 2016). This study aims to provide an additional factor related to the dividend policy - the degree of total leverage within banking context.

A bank with a relatively high fixed-to-variables costs is considered as one with a high degree of total leverage (DTL), and banks with high DTL have cash-flow highly sensitive to revenues changes (DeYoung \& Roland, 2001). A small reduce in revenues could lead to a large reduce in earnings in high DTL banks since such banks have to spend a relatively large fraction of each decreased revenue dollar. In such situation, high DTL banks are more likely to encounter financial distress. Hence, one may suggest banks with high DTL are less likely to pay dividends, and spend lower fraction of income to pay dividends. This conservatism in dividend policy is due to the precautionary motives aimed at preserving corporate resources during distress times.

We examine the effects of DTL on bank dividend policy for a large sample of US bank holding companies (BHC) during 2000:Q1 and 2017:Q4. Our empirical analysis provides consistent evidence on a higher conservatism in 
dividend policy of banks subject to high DTL. To ensure the robustness of our finding, we provide a battery of sensitivity tests. The evidence remains unchanged when we use the propensity score matching (PSM), alternative measures of dividends and DTL.

Recent studies point out that during the financial crises, the conflicts between creditors and shareholders become more serious. Since bank's franchise value is smaller, banks have higher vocation to pay out to shareholders rather than to transfer cash to creditors in case of defaults (Acharya, Le, \& Shin, 2016; Tran \& Ashraf, 2018). Hence, one could expect high DTL banks which face further difficulties during crisis have higher incentives to pay dividends. However, one may suggest that high DTL banks could become more conservative in their dividend policy to deal better to the crisis. Our results do not support these both expectations. We do find there is no difference in the impacts of DTL on the dividend policy during the crisis versus normal times. When we focus on banks with low franchise value as defined by the level of Tier-1 capital ratio, the negative relation between DTL and dividend policy is more pronounced with these banks during the financial crises. This finding suggests that the agency problems between creditors and shareholders do not affect the relation between DTL and dividend policy. Rather, it shows that the conservatism in dividend policy of high DTL banks seems to be related to the precautionary motives aimed at preserving corporate resources under financial distress.

However, one could suggest that the conservatism of dividend policy in high DTL banks may be derived from the self-interested managers who do not act in the interests of the shareholders and seek for private benefits of control. Hence, the conservative dividend policy observed in high DTL banks could be not in the purpose of maximizing the shareholder value, but is dedicated to the private benefits of managers. To address this concern, we adopt the established methodology pioneered by Fama and French (1998) which aims to examine the marginal value of dividends. If the lower amount of dividends observed in banks with high DTL reflect the private benefits of controls of managers, dividend payback should be related to a higher value than those from low DTL banks, since paying back to shareholders reduces the available funds for managers.

On the contrary, if it is not derived from the managerial discretion, but for precautionary reason, dividend payback in high DTL banks should be related to a lower value than those from low DTL banks, since paying dividends may involve banks to higher probabilities of financial distress. We do find that an additional dollar of current dividend (DIV) is associated with a higher increase of additional value in low DTL banks than in high DTL banks, suggesting that our evidence so far is not concerned by the managerial self-interest.

Recently, Kulchania (2016) documents that cost structure is an important determinant in the decision of payout policy in non-financial firms. Our study contributes to the literature of cost structure and dividend policy by pointing out that the impacts of the degree of fixed-to-variable expenses to dividend policy are extended to the case of banks.

We develop our hypotheses in the next section. Section III describes the data. Section IV reports the results from our main framework. We examine the effects of the crisis in Section V, and provide robustness checks in Section VI. Section VII discusses the finding, and identifies the foundation of the relation between total leverage and bank dividend policy. Section VIII concludes the study.

\section{Hypothesis Development}

A bank with a relatively high fixed-to-variables costs is considered as one with a high degree of total leverage (DTL) (DeYoung \& Roland, 2001). Fixed costs could be the fixed or quasi-fixed operating costs (e.g. labor, offices ...) or fixed financing expenses. Banks with high DTL have cash-flow highly sensitive to revenues. When revenues increase, high DTL banks can enjoy higher earnings as the increases in revenues are higher than the increases in costs. In contrast, a small reduce in revenues could lead to a large reduce in earnings in high DTL banks since such banks have to spend a relatively large fraction of each decreased revenue dollar. In such situation, high DTL banks could face funds shortfall, and have difficulties to raise external funds since additional raising funds are firstly served to fixed operating and financial expenses. Furthermore, these banks are more likely to encounter financial distress. Hence, one may suggest banks with high DTL are more conservative in dividend policy due to the precautionary motives aimed at preserving corporate resources.

Recent studies point out that during the financial crises, the conflicts between creditors and shareholders become more serious. The crisis has negative effects on bank's earnings, especially for high DTL banks which cannot adjust quickly their costs due to high fraction of fixed costs. One may expect that since the franchise value of high DTL banks become smaller than low DTL banks, they are more likely to pay out to shareholders rather than to transfer cash to creditors in case of defaults (e.g. Acharya, Le, \& Shin, 2016). However, one may suggest that high DTL banks could become more conservative in their dividend policy to deal better to the crisis. Since most banks in our sample curtail their dividends, our hypothesis is based on the greater conservatism of dividend policy during the crisis. 


\section{Data and Research Methods}

\subsection{Sample}

The Federal Reserve provides quarterly Y-9C regulatory reports filled by bank holding companies (BHC) with assets of $\$ 150$ million and over. Our raw data cover the period 2001:Q1 to 2017:Q4. We next remove any bank-quarters observations with missing or incomplete financial data on basis accounting variables of the main model of regression. Following Berger and Bouwman (2013) and Berger, Ghoul, Guedhami, and Roman (2016), we replace all observation with ratio of total equity over total assets less than $1 \%$ by $1 \%$ to avoid distortion in ratios that contain equity, and also exclude observations with negative or no outstanding loans or deposits. Since we compute the degree of total leverage over the window of 12 quarters, our final quarter lasts from 2000:Q1-2017:Q4. All financial ratios are winsorized at 1\% level on the top and bottom of their distribution to dampen the effects of outliers.

\subsection{Variables}

The total leverage captures the sensitivity of earnings growth to revenues growth. Banks with high fixed-tovariables costs have higher sensitivities, and as a consequent, higher degree of total leverage. We construct DTL following DeYoung and Roland (2001) which make some modifications from the approach of Mandelker and Rhee (1984), O'Brien and Vanderheiden (1987) to adapt to the multiproduct nature of banks. We explain the construction in Appendix A. We also use an alternative approach to compute DTL (See Appendix B), and still find similar results.

To explain the decision to pay or not, we use DUM_DIV equal to one if bank pay dividend at time $t$, and zero otherwise. We use DPO which is the dividend payout defined as the ratio of dividend over net income. We set DPO equal to one when dividends are higher than net income, and zero with negative income banks that pay dividends. Our results remain unchanged with alternative measures of payout ratio.

In order to mitigate a potential omitted variable bias, we control for various bank-specific variables, as well as time (quarters) fixed effects. Following prior literature (e.g. Fama \& French, 2001; Abreu \& Gulamhussen, 2013), the bank-specific control variables are as follows: SIZE which is the natural logarithm of the book value of gross total assets; CAPITAL defined by the ratio of total equity over the gross total assets; EARNINGS as the earnings before taxes and loan loss provisions scaled to gross total assets; VOLATILITY as the standard deviation over 12 quarters of EARNINGS; GROWTH defined as the growth of assets (Table 1).
Table 1: Variables Definitions

\begin{tabular}{|c|c|}
\hline Variable & Definition \\
\hline \multicolumn{2}{|r|}{ Dependent Variables } \\
\hline DUM_DIV & $\begin{array}{l}\text { A dummy that takes a value of } 1 \text { if the bank pays } \\
\text { dividend at time } t \text { and } 0 \text { otherwise. }\end{array}$ \\
\hline DPO & Ratio of dividend over net income \\
\hline \multicolumn{2}{|r|}{ Variables of Interest } \\
\hline DTL & See Appendix A \\
\hline \multicolumn{2}{|r|}{ Control Variables } \\
\hline SIZE & The natural logarithm of gross total assets \\
\hline CAPITAL & Book value of equity over gross total assets \\
\hline EARNINGS & $\begin{array}{l}\text { Income before taxes, provisions recognized in } \\
\text { income over gross total assets }\end{array}$ \\
\hline VOLATILITY & $\begin{array}{l}\text { Standard deviation of premanaged earnings over the } \\
\text { previous } 12 \text { quarters ( } \mathrm{t}-11 \text { to } \mathrm{t} \text { ) }\end{array}$ \\
\hline GROWTH & Growth of assets over quarter \\
\hline
\end{tabular}

\subsection{Summary Statistics}

Table 2 reports the summary descriptive of these variables. On average, the banks in our sample spend nearly $30 \%$ of their income to pay back their shareholders. The fraction of payers is also high, almost $70 \%$ banks decide to pay dividends. In Table 2 Panel B, I order banks by the degree of total leverage. Specifically, in each quarter, we divide the sample into quartile based on DTL, and assign banks to high DTL group as banks are belong to top quartile of DTL, banks to low DTL group as banks are belong to bottom quartile of DTL. The medium group contains banks that are belong to the second and third quartile of DTL. We observe that banks in highest quartile spend lower fraction of income to pay back dividends, and are less likely to pay dividends than banks in lowest quartile. The differences are significant at $1 \%$ level. Banks in highest quartile seem to be smaller, less capitalized, less performed, riskier and have lower growth opportunities than banks in lowest quartile. In Table 2 Panel C, we note that DPO and DUM_DIV are negatively correlated with DTL. Furthermore, the pairwise correlation between the main variables are relatively low, suggesting that our results are not concerned by the multicollinearity. In summary, the results in Table (2) are in line with our H1.

This table reports summary statistics for the main sample of U.S. Bank Holding Companies (BHC) used in the analysis. Panel A presents descriptive statistics; Panel B shows the mean values of variables by quartile of DTL. In each quarter, we divide our sample into quartile based on $D T L$. High DTL banks are belong to top quartile whereas low DTL are belong to bottom quartile. The difference shows the difference between high DTL versus low DTL sample. We conduct t-test to examine the significance of the difference. Table 2 Panel $\mathrm{C}$ presents the correlation matrix for the regression variables. 
Table 2: Summary Statistics and Univariate Tests

Panel A: Descriptive Statistics

\begin{tabular}{|l|c|c|c|c|c|}
\hline & Mean & Q1 & Median & Q3 & SD \\
\hline DPO & 0.297 & 0.000 & 0.251 & 0.478 & 0.307 \\
\hline DUM_DIV & 0.683 & 0.000 & 1.000 & 1.000 & 0.465 \\
\hline DTL & 2.697 & 0.327 & 0.856 & 2.300 & 5.480 \\
\hline SIZE & 13.969 & 13.234 & 13.710 & 14.413 & 1.185 \\
\hline CAPITAL & 0.092 & 0.075 & 0.089 & 0.105 & 0.028 \\
\hline EARNINGS & 0.015 & 0.011 & 0.015 & 0.020 & 0.009 \\
\hline VOLATILITY & 0.005 & 0.002 & 0.003 & 0.005 & 0.007 \\
\hline GROWTH & 0.017 & -0.006 & 0.012 & 0.032 & 0.042 \\
\hline
\end{tabular}

Panel B: Mean Values by Quartile of DTL

\begin{tabular}{|c|c|c|c|c|}
\hline & Lowest Quartile of DTL(1) & $2^{\text {nd }}$ and $3^{\text {rd }}$ Quartile of DTL(2) & Highest quartile of DTL(3) & $\begin{array}{l}\text { Difference } \\
(4)=(3)-(1)\end{array}$ \\
\hline DPO & 0.316 & 0.314 & 0.244 & $-0.072 * * *$ \\
\hline DUM_DIV & 0.732 & 0.704 & 0.591 & $-0.141 * * *$ \\
\hline SIZE & 14.108 & 13.966 & 13.836 & $-0.272 * * *$ \\
\hline CAPITAL & 0.094 & 0.093 & 0.089 & $-0.005 * * *$ \\
\hline EARNINGS & 0.018 & 0.016 & 0.012 & $-0.005 * * *$ \\
\hline VOLATILITY & 0.004 & 0.005 & 0.008 & $0.005 * * *$ \\
\hline GROWTH & 0.020 & 0.018 & 0.011 & $-0.009 * * *$ \\
\hline
\end{tabular}

Panel C: Correlation Matrix

\begin{tabular}{|l|c|c|c|c|c|c|c|}
\hline & DPO & DUM_DIV & DTL & SIZE & CAPITAL & EARNINGS & VOLATILITY \\
\hline DPO & 1 & & & & & \\
\hline DUM_DIV & $0.662^{* * *}$ & 1 & & & & \\
\hline DTL & $-0.118^{* * *}$ & $-0.136^{* * *}$ & 1 & & & & \\
\hline SIZE & -0.008 & $0.163^{* * *}$ & $-0.115^{* * *}$ & 1 & & & \\
\hline CAPITAL & $0.057^{* * *}$ & $0.078^{* * *}$ & $-0.076^{* * *}$ & $0.085^{* * *}$ & 1 & & \\
\hline EARNINGS & $0.125^{* * *}$ & $0.202^{* * *}$ & $-0.169^{* * *}$ & $0.113^{* * *}$ & $0.351^{* * *}$ & 1 & \\
\hline VOLATILITY & $-0.157^{* * *}$ & $-0.165^{* * *}$ & $0.187^{* * *}$ & $0.121^{* * *}$ & $0.099^{* * *}$ & $-0.101^{* * *}$ & 1 \\
\hline GROWTH & $0.025^{* * *}$ & $0.058^{* * *}$ & $-0.064^{* * *}$ & $0.037^{* * *}$ & $-0.041^{* * *}$ & $0.134^{* * *}$ & $-0.089^{* * *}$ \\
\hline
\end{tabular}

\section{Results}

The evidence on the relation between DTL with dividend policy from univariate tests may omit a number of factors that could have impacts with both bank dividend policy and total leverage. In this section, we conduct multivariate analysis to formally investigate how the total leverage (DTL) affects the question of whether to pay (the decision to pay dividends), and of how much to pay (the amount of the payout) after controlling other control variables. Specifically, the empirical specification we estimate is as follows:

$D I V_{i t}=\alpha+D_{T L} L_{i t-1}+$ CONTROL $_{i t-1}+\theta_{t}+\varepsilon_{i t}$

where DIV is the proxy of dividend policy (i.e. DPO or DUM_DIV). Our variable of interest is DTL. CONTROL is the vector of control variables that are described above. All variables are lagged one quarter to control for potential endogeneity. We include time-fixed effects, $\theta_{t}$, to control for time effects, which can affect the discretionary behaviors of banks. $\varepsilon_{i t}$ is the error term. Since banks dividends are likely to be correlated within a bank over time, standard errors used to assess significance are corrected for heteroscedasticity and bank-level clustering.

\subsection{Decision to Pay and DTL}

Table 3 shows the results. We first begin with the question of whether to pay or not. For this end, we use the logit regression. Our baseline model (Model (1)) indicates that high DTL induces low propensity to pay dividends, as indicated by the negative and significant coefficient on DTL. 
Since DTL is measured with potential errors, we create indicator variables that reflect the tail distribution of DTL. Specifically, for each quarter, we divide our sample into quartile based on DTL. We create HIGH_DTL (LOW_DTL) equal to one if banks are belonging to top (bottom) quartile, and zero otherwise. The results in Model (2) point out that banks with high DTL are less likely to pay dividends.

Table 3: Dividend Policy and DTL

\begin{tabular}{|c|c|c|c|c|c|c|c|c|}
\hline & & & Deper & t Variable= & M_DIV & & dent Variabl & DPO \\
\hline & Baseline & $\begin{array}{l}\text { High/Low } \\
\text { DTL }\end{array}$ & $\begin{array}{c}\text { Add. } \\
\text { Variables }\end{array}$ & PSM & Baseline & $\begin{array}{l}\text { High/Low } \\
\text { DTL }\end{array}$ & $\begin{array}{c}\text { Add. } \\
\text { Variables }\end{array}$ & PSM \\
\hline & (1) & (2) & (3) & (4) & (5) & (6) & (7) & $(8)$ \\
\hline DTL & $-0.030 * * *$ & & $-0.029 * * *$ & $-0.044 * * *$ & $-0.008 * * *$ & & $-0.005 * *$ & $-0.004 * * *$ \\
\hline & $(0.007)$ & & $(0.007)$ & $(0.008)$ & $(0.002)$ & & $(0.002)$ & $(0.001)$ \\
\hline HIGH_DTL & & $-0.242 * * *$ & & & & $-0.066^{* * *}$ & & \\
\hline & & $(0.081)$ & & & & $(0.017)$ & & \\
\hline LOW_DTL & & -0.028 & & & & -0.017 & & \\
\hline & & $(0.084)$ & & & & $(0.014)$ & & \\
\hline SIZE & $0.429 * * *$ & $0.434 * * *$ & $0.462 * * *$ & $1.161 * * *$ & $0.013 *$ & $0.014 *$ & -0.012 & 0.072 \\
\hline & $(0.064)$ & $(0.064)$ & $(0.066)$ & $(0.260)$ & $(0.007)$ & $(0.007)$ & $(0.008)$ & $(0.046)$ \\
\hline CAPITAL & $3.766^{*}$ & $4.038^{*}$ & 3.238 & $21.515^{* * *}$ & $0.939 * *$ & $1.001 * *$ & $1.458 * * *$ & $1.155^{* *}$ \\
\hline & $(2.194)$ & (2.184) & $(2.131)$ & (3.143) & $(0.419)$ & $(0.418)$ & $(0.527)$ & $(0.453)$ \\
\hline EARNINGS & $37.615 * * *$ & $37.891^{* * *}$ & $20.100 * * *$ & $43.154^{* * *}$ & $8.799 * * *$ & $8.922 * * *$ & $-2.689 *$ & -1.175 \\
\hline & $(5.661)$ & $(5.750)$ & $(5.936)$ & $(5.897)$ & $(1.098)$ & $(1.118)$ & $(1.409)$ & $(0.749)$ \\
\hline VOLATILITY & $-43.268 * * *$ & $-44.309 * * *$ & $-34.180 * * *$ & $-57.053 * * *$ & $-10.442 * * *$ & $-10.836 * * *$ & $-4.179 * *$ & -1.529 \\
\hline & $(7.670)$ & $(7.775)$ & $(7.304)$ & $(8.838)$ & $(1.631)$ & $(1.635)$ & $(1.836)$ & $(0.953)$ \\
\hline GROWTH & -0.160 & -0.100 & -0.894 & $1.598^{* *}$ & -0.141 & -0.121 & -0.236 & 0.043 \\
\hline & $(0.620)$ & $(0.618)$ & $(0.612)$ & $(0.799)$ & $(0.127)$ & $(0.127)$ & $(0.144)$ & $(0.078)$ \\
\hline AGE & & & $0.052^{* *}$ & -0.515 & & & -0.004 & 0.115 \\
\hline & & & $(0.024)$ & $(0.370)$ & & & $(0.005)$ & $(0.072)$ \\
\hline LOSS & & & $-1.320 * * *$ & $-1.103 * * *$ & & & $-0.417 * * *$ & $-0.138^{* * *}$ \\
\hline & & & $(0.111)$ & $(0.143)$ & & & $(0.035)$ & $(0.020)$ \\
\hline TOBIN'Q & & & & & & & $1.028 * * *$ & $0.836^{* * *}$ \\
\hline & & & & & & & $(0.204)$ & $(0.171)$ \\
\hline FIRST DPO & & & & & & & $0.552 * * *$ & \\
\hline & & & & & & & $(0.077)$ & \\
\hline Constant & $-5.014 * * *$ & $-5.285 * * *$ & $-5.908 * * *$ & & 0.008 & -0.054 & $-0.712 * *$ & $-3.392 * *$ \\
\hline & $(0.866)$ & $(0.864)$ & $(0.991)$ & & $(0.107)$ & $(0.107)$ & $(0.278)$ & $(1.313)$ \\
\hline BFE & No & No & Yes & No & No & No & Yes & No \\
\hline QFE & Yes & Yes & Yes & Yes & Yes & Yes & Yes & Yes \\
\hline Observations & 16,872 & 16,872 & 16,872 & 8,675 & 16,916 & 16,916 & 5,209 & 5,209 \\
\hline $\begin{array}{l}\text { Pseudo/Adjuste } \\
\text { d R2 }\end{array}$ & 0.0971 & 0.0951 & 0.114 & 0.182 & 0.0618 & 0.0599 & 0.292 & 0.141 \\
\hline
\end{tabular}

Panel A reports regression estimates of the relation between dividend policy and the degree of total leverage. The dependent variables are $D U M+D I V$ for Models (1)-(4), and DPO for Models (5)-(9). Models (1)-(4) report the results of Logit regressions. Models (5), (6), (8) report the results of Tobit regressions. Model (7) reports the results of OLS regressions. All regressions include time (quarter) fixed effects. Panel B reports the differences in mean between actual $D P O$ and predicted $D P O$ of $H I G H \_D T L$ banks. All financial variables are winsorized at $1 \%$ level on top and bottom of the distribution. ***, $* *, *$ indicate significance at the $1 \%, 5 \%$, and $10 \%$ level respectively. Standard errors are clustered at the bank level. Numbers in parentheses are tstatistics.

Although we use control variables based on those widely used in the literature on dividends, there are some additional variables suggested by other studies. To ensure that the negative correlation between DUM_DIV and DTL is not driven by correlated omitted variables, we include the following variables in Model (2): (natural logarithm) bank's age (AGE), LOSS equal to one if banks experience negative income at time $t$, and zero otherwise. We also include bank fixed-effects as an endogeneity control when the unobservable correlated with DTL and dividend policy remain unchanged over time. Our main finding remains unchanged with the inclusion of these additional variables 
(Model (3)). The coefficient on DTL continues to be negative and statistically significant, indicating high DTL reduce banks propensity to pay dividends.

Even that we still find the same conclusion with the inclusion of bank fixed-effects, we employ the propensity scores matching (PSM) to better control for differences in characteristics between high DTL and low DTL banks. For this end, we create a dummy which equals to one if banks are belong to highest quartile of DTL (treated group), and zero for banks that belong to lowest quartile of DTL (untreated group). We next measure the propensity of undergoing treatment by using a probit model for both treated and untreated samples. Then, we match high DTL bank to low DTL bank sharing similar characteristics as reflected in their propensity scores (with replacement) ${ }^{3}$. The result from PSM sample (Model (4)) is consistent with previous findings.

Regardless control variables, large, well-capitalized and high-performance banks are more likely to pay dividends, whereas banks with high volatility in earnings tend not to payout. We do not evidence for growth opportunities. For additional variables, high maturity banks are more likely to payout whereas banks that experience loss are not.

\subsection{Dividend Payout and DTL}

We continue with the investigation of the impacts of DTL on the amount that banks pay back. The results are shown in Table (3), Models (5)-(9). We use Tobit regression for this end. ${ }^{4}$ Our baseline model (Model (5)) indicates that banks with higher DTL spend a lower fraction of income on dividends, as indicated by the negative and significant coefficient on DTL. As above, we replace DTL by two indicator variables (HIGH_DTL, and LOW_DTL), and still find similar result. We include additional variables such as AGE, LOSS, and bank fixed-effects. We also add initial values of the dependent variable as Lemmon, Roberts, and Zender (2008) to control for the persistence of dependent variable. Our results remain unchanged. Finally, we end up using PSM, and DTL remains negatively related to the amount of payout.

\section{Dividend Policy and Bank Opacity}

We use the financial crises as natural quasi-experiment to examine whether the total leverage affects differently

\footnotetext{
${ }^{3}$ We retain only untreated observations whose the propensity scores fall inside the interval defined for the treated group. We impose a tolerance level of $0.5 \%$ on the maximum propensity score distance allowed (caliper) to minimize the risk of bad matches. Our results remain unchanged with no replacement.

${ }^{4}$ The use of OLS do not change our results.
}

banks' dividend policy. Following Berger and Bouwman (2013), Tran and Ashraf (2018), Tran, Hassan, and Houston (2019), Tran, Hassan, and Houston (2019) in identifying the financial crises, our sample contains the banking crises from 2007:Q3 to 2009:Q4. The results are reported in Table (4). We first investigate how DTL affects the decision to pay dividends and the amount to pay during the financial crises by including the interaction term DTL*FI_CRISES in Model (1) and (2). In both specifications, the interaction terms are negative but not significant, suggesting that there is no difference in the impacts of DTL on the decision to pay and the amount to pay during the crisis versus normal times (Table 4).

This table reports regression estimates of the relation between dividend policy and the degree of total leverage during the financial crisis. The dependent variables are $D U M \_D I V$ for Models (1) and (3), and DPO for Models (2) and (4). Models (1) and (3) report the results of Logit regressions. Models (2) and (4) report the results of Tobit regressions. All regressions include time (quarter) fixed effects. All financial variables are winsorized at $1 \%$ level on top and bottom of the distribution. ***,**,* indicate significance at the $1 \%, 5 \%$, and $10 \%$ level respectively. Standard errors are clustered at the bank level. Numbers in parentheses are t-statistics.

One could suspect that banks with different financial conditions would behavior differently in their dividend policy. Acharya, Le, and Shin (2016) state the risk-shifting behavior in the dividend policy of low franchise value banks. Therefore, we focus on banks with low franchise value. Specifically, in each quarter, we divide our sample into quartile based on the ratio of Tier-1 capital over riskweighted-assets (T1R). We create LOW_T1R which equals one if banks are at the bottom quartile of TIR, and zero otherwise. We re-estimate Equation (1) by including LOW_T1R and its interactions with DTL, and DTL ${ }^{*}$ CRISES. The results are shown in Models (3)-(4).

Banks with low franchise value are less likely to pay dividends, and spend a lower fraction of income on dividends during the financial crises as indicated by the negative coefficient on DTL*CRISES*LOW_T1R, whereas there is no difference in the propensity to pay and the amount to pay between these low T1R banks and other banks. This finding suggests that the agency problems between creditors and shareholders do not affect the relation between DTL and dividend policy. Rather, it shows that the conservatism in dividend policy of high DTL banks seems to be related to the precautionary motives aimed at preserving corporate resources under financial distress (Table 5). 
Table 4: Dividend Policy and DTL during the Financial Crisis

\begin{tabular}{|c|c|c|c|c|}
\hline & DUM_DIV & DPO & DUM_DIV & DPO \\
\hline & (1) & (2) & (3) & (4) \\
\hline \multirow[t]{2}{*}{ DTL } & $-0.030 * * *$ & $-0.007 * * *$ & $-0.028 * * *$ & $-0.007 * * *$ \\
\hline & $(0.007)$ & $(0.002)$ & $(0.008)$ & $(0.002)$ \\
\hline \multirow[t]{2}{*}{ DTL*CRISES } & -0.005 & -0.009 & 0.016 & -0.004 \\
\hline & $(0.020)$ & $(0.006)$ & $(0.021)$ & $(0.006)$ \\
\hline \multirow{2}{*}{ DTL*CRISES*LOW_T1R } & & & $-0.170 * *$ & $-0.058^{* *}$ \\
\hline & & & $(0.066)$ & $(0.026)$ \\
\hline \multirow[t]{2}{*}{ DTL*LOW_T1R } & & & -0.006 & -0.000 \\
\hline & & & $(0.012)$ & $(0.003)$ \\
\hline \multirow[t]{2}{*}{ LOW_T1R } & & & $-0.673 * * *$ & $-0.113 * * *$ \\
\hline & & & $(0.126)$ & $(0.023)$ \\
\hline \multirow[t]{2}{*}{ SIZE } & $0.429 * * *$ & $0.013 *$ & $0.465 * * *$ & $0.019^{* *}$ \\
\hline & $(0.064)$ & $(0.007)$ & $(0.064)$ & $(0.008)$ \\
\hline \multirow[t]{2}{*}{ CAPITAL } & $3.764 *$ & $0.939 * *$ & -1.395 & 0.172 \\
\hline & $(2.193)$ & $(0.419)$ & $(2.240)$ & $(0.437)$ \\
\hline \multirow[t]{2}{*}{ EARNINGS } & $37.507 * * *$ & $8.625 * * *$ & $37.526 * * *$ & $8.525^{* * *}$ \\
\hline & $(5.692)$ & $(1.110)$ & $(5.690)$ & (1.109) \\
\hline \multirow[t]{2}{*}{ VOLATILITY } & $-43.179 * * *$ & $-10.278 * * *$ & $-40.188 * * *$ & $-9.673 * * *$ \\
\hline & $(7.629)$ & $(1.625)$ & $(7.294)$ & $(1.591)$ \\
\hline \multirow[t]{2}{*}{ GROWTH } & -0.162 & -0.142 & 0.119 & -0.098 \\
\hline & $(0.620)$ & $(0.127)$ & $(0.622)$ & $(0.125)$ \\
\hline \multirow[t]{2}{*}{ Constant } & $-5.015 * * *$ & 0.004 & $-4.871 * * *$ & 0.011 \\
\hline & $(0.866)$ & $(0.106)$ & $(0.851)$ & $(0.105)$ \\
\hline QFE & Yes & Yes & Yes & Yes \\
\hline Observations & 16,872 & 16,916 & 16,866 & 16,910 \\
\hline Pseudo R2 & 0.0971 & 0.0622 & 0.109 & 0.0695 \\
\hline
\end{tabular}

Table 5: Alternative Measures of Dividends and DTL

Panel A: Alternative Measures of Dividends

\begin{tabular}{|c|c|c|c|c|c|c|c|c|}
\hline & DPO_AVG & DPO_2 & DIV/CAP & DIV/ASSETS & DPS & REPUR & DUM_REPUR & DUM_REPUR_NODIV \\
\hline & (1) & $(2)$ & (3) & (4) & $(5)$ & $(6)$ & $(7)$ & $(8)$ \\
\hline \multirow[t]{2}{*}{ DTL } & $-0.004 * * *$ & $-0.008 * * *$ & $-0.001 * * *$ & $-0.000 * * *$ & $-0.003 * * *$ & $-0.004 *$ & -0.003 & $0.051 * * *$ \\
\hline & $(0.001)$ & $(0.001)$ & $(0.000)$ & $(0.000)$ & $(0.001)$ & $(0.002)$ & $(0.014)$ & $(0.017)$ \\
\hline \multirow[t]{2}{*}{ SIZE } & 0.006 & 0.014* & 0.000 & 0.000 & $0.030 * * *$ & $0.091 * * *$ & $0.640 * * *$ & $0.260 * * *$ \\
\hline & $(0.005)$ & $(0.007)$ & $(0.001)$ & $(0.000)$ & $(0.006)$ & $(0.015)$ & $(0.067)$ & $(0.098)$ \\
\hline \multirow[t]{2}{*}{ CAPITAL } & 0.312 & $1.184 * * *$ & $-0.150 * *$ & $0.025^{* * *}$ & 0.152 & $1.875^{* * *}$ & $5.819 * *$ & $11.525 * *$ \\
\hline & $(0.250)$ & $(0.407)$ & $(0.067)$ & $(0.007)$ & $(0.275)$ & $(0.598)$ & $(2.672)$ & $(4.723)$ \\
\hline \multirow[t]{2}{*}{ EARNINGS } & $2.995 * * *$ & $9.112 * * *$ & $2.531 * * *$ & $0.234 * * *$ & $3.460 * * *$ & -0.406 & -0.537 & -25.772 \\
\hline & $(0.658)$ & $(1.058)$ & $(0.228)$ & $(0.022)$ & $(0.672)$ & $(1.634)$ & $(8.985)$ & $(19.698)$ \\
\hline \multirow[t]{2}{*}{ VOLATILITY } & $-4.786 * * *$ & $-10.887 * * *$ & $-0.876^{* * *}$ & $-0.059 * *$ & $-3.795 * * *$ & $-11.697 * * *$ & $-40.817 * * *$ & -9.573 \\
\hline & $(0.829)$ & $(1.634)$ & $(0.223)$ & $(0.025)$ & $(0.726)$ & $(2.990)$ & $(12.302)$ & (19.388) \\
\hline \multirow[t]{2}{*}{ GROWTH } & $-0.233^{* * *}$ & -0.180 & $-0.033^{*}$ & $-0.004 * *$ & $-0.198 * * *$ & $-0.344 *$ & -1.204 & 0.801 \\
\hline & $(0.064)$ & $(0.122)$ & $(0.018)$ & $(0.002)$ & $(0.064)$ & $(0.176)$ & $(0.833)$ & $(2.728)$ \\
\hline \multirow[t]{2}{*}{ Constant } & $0.193 * * *$ & -0.043 & $0.028^{*}$ & -0.001 & $-0.312^{* * *}$ & $-1.762 * * *$ & $-11.314 * * *$ & $-10.953 * * *$ \\
\hline & $(0.074)$ & $(0.104)$ & $(0.014)$ & $(0.001)$ & $(0.084)$ & $(0.203)$ & $(0.976)$ & $(2.080)$ \\
\hline QFE & Yes & Yes & Yes & Yes & Yes & Yes & Yes & Yes \\
\hline Observations & 18,954 & 18,992 & 18,943 & 18,943 & 6,028 & 18,992 & 16,917 & 16,551 \\
\hline Pseudo R2 & 0.320 & 0.0663 & -0.134 & -0.0428 & -0.645 & 0.0571 & 0.128 & 0.0568 \\
\hline
\end{tabular}

Panel A reports regression estimates of the relation between dividends and alternative measures of DTL (DTL_18,DTL_20,DTL_TRANS). The dependent variables are DUM DIV for Models (1)-(3), and DPO for Models (4)-(6). Models (1)-(3) report the results of Logit regressions. Models (4)-(6) report the results of Tobit regressions. Panel B reports regression estimates of the relation between alternative dividend measures and DTL. Models (1)-(6) report the results of Tobit regressions. Models (7)-(8) report the results of Logit regressions. All regressions include time (quarter) fixed effects. All financial variables are winsorized at $1 \%$ level on top and bottom of the distribution. $* * *, * * *$ indicate significance at the $1 \%, 5 \%$, and $10 \%$ level respectively. Standard errors are clustered at the bank level. Numbers in parentheses are t-statistics. 
Panel B: Alternative Measures of DTL

\begin{tabular}{|l|l|l|l|l|l|l|}
\hline & \multicolumn{2}{|c|}{ Dependent Variable=DUM_DIV } & \multicolumn{3}{c|}{ Dependent Variable=DPO } \\
\hline & \multicolumn{1}{|c|}{ DTL_18 } & \multicolumn{1}{|c|}{ DTL_20 } & \multicolumn{1}{c|}{ DTL_TRANS } & \multicolumn{1}{c|}{ DTL_18 } & \multicolumn{1}{c|}{ DTL_20 DTL_TRANS } \\
\hline & $(1)$ & $(2)$ & $(3)$ & $(4)$ & $(5)$ & $(6)$ \\
\hline DTL & -0.005 & $-0.018^{* * *}$ & $-0.035^{* * *}$ & $-0.002^{*}$ & $-0.006^{* * *}$ & $-0.009^{* * *}$ \\
\hline & $(0.004)$ & $(0.007)$ & $(0.007)$ & $(0.001)$ & $(0.002)$ & $(0.001)$ \\
\hline SIZE & $0.415^{* * *}$ & $0.416^{* * *}$ & $0.451^{* * *}$ & 0.012 & 0.010 & $0.016^{*}$ \\
\hline & $(0.072)$ & $(0.075)$ & $(0.083)$ & $(0.008)$ & $(0.009)$ & $(0.008)$ \\
\hline CAPITAL & $6.514^{* *}$ & $6.086^{* *}$ & $11.747^{* * *}$ & $1.265^{* *}$ & $1.156^{* *}$ & $2.637^{* * *}$ \\
\hline & $(2.795)$ & $(3.088)$ & $(2.387)$ & $(0.502)$ & $(0.556)$ & $(0.406)$ \\
\hline EARNINGS & $43.607^{* * *}$ & $46.710^{* * *}$ & $37.170^{* * *}$ & $10.399^{* * *}$ & $11.304^{* * *}$ & $8.934^{* * *}$ \\
\hline & $(6.394)$ & $(6.813)$ & $(8.918)$ & $(1.187)$ & $(1.252)$ & $(1.550)$ \\
\hline VOLATILITY & $-47.004^{* * *}$ & $-43.537^{* * *}$ & $-70.363^{* * *}$ & $-11.644^{* * *}$ & $-10.910^{* * * *}$ & $-18.207^{* * *}$ \\
\hline & $(9.494)$ & $(9.749)$ & $(12.927)$ & $(1.980)$ & $(2.069)$ & $(2.365)$ \\
\hline GROWTH & $1.666^{* *}$ & $2.431^{* * *}$ & -0.350 & $0.243^{*}$ & $0.416^{* * *}$ & -0.128 \\
\hline & $(0.695)$ & $(0.790)$ & $(0.744)$ & $(0.132)$ & $(0.143)$ & $(0.139)$ \\
\hline Constant & $-5.492^{* * *}$ & $-5.292^{* * *}$ & $-6.188^{* * *}$ & -0.092 & -0.074 & $-0.235^{* *}$ \\
\hline & $(0.946)$ & $(1.030)$ & $(1.062)$ & $(0.117)$ & $(0.130)$ & $(0.113)$ \\
\hline QFE & Yes & Yes & Yes & Yes & Yes & Yes \\
\hline Observations & 13,266 & 11,650 & 13,625 & 13,304 & 11,683 & 13,668 \\
\hline Pseudo R2 & 0.116 & 0.125 & 0.156 & 0.0746 & 0.0833 & 0.110 \\
\hline
\end{tabular}

\section{Robustness Checks}

The negative relationship between bank dividend policy and DTL documented above could be driven by the choice of the measures of dividends, and of DTL. To mitigate these concerns, we next re-estimate our baseline model with alternative measures of these variables.

\subsection{Alternative measures of dividends}

In this section, we re-estimate Equation (1) with different measures of dividends. The results are shown in Table 5, Panel A. First, we use an average of DPO over 12 previous quarters (DPO_AVG), DPO_2 without setting upper bound (i.e. equals to one if dividends are higher than net income) in Models (1), (2) respectively. We also scale dividends over equity (DIV/CAP), over assets (DIV/ASSETS) to mitigate the problem of negative income in Models (3), (4) respectively. We employ DPS, the dividends per shares in Model (5). In all specifications, the results remain unchanged.

Stock repurchases are considered as alternative way that firms can return capital to shareholders since early 1980s, offer higher flexibility and tax advantages, and could be a substitute for dividends (Skinner, 2008). While dividends are steadily over time, and implicitly permanent commitments, repurchases however are very pro-cyclical, and do not involve an ongoing commitment. Repurchases are used for distribute transient cash-flow shocks in case of high earnings (Guay \& Harford, 2000; Jagannathan, Stephens, \& Weisbach, 2000; Hirtle, 2004), and are less useful as signals (Floyd, Li, \& Skinner. 2015). Hence, repurchases offer to managers more discretion than dividends do. Empirical studies document negative market reactions after changes of dividends (Healy \& Palepu, 1988; Grullon \& Michaely, 2002) for firms, and Bessler and Nohel $(1996,2000)$ for banks, whereas there is mixed evidence on markets reactions for changes of repurchases ${ }^{5}$. Therefore, the question on the relation between bank opacity and share repurchases is still ambiguous. We employ REPUR, the amount of stock repurchases scaled to net income.

We also create DUM_REPUR which equals to one if bank repurchases at time $t$, and zero otherwise. Since REPUR could include banks that pay dividends, we are concern that the effects of dividends paying could outweigh those from repurchases. Therefore, we create an indicator variable, DUM_REPUR_NODIV which equals to one if bank repurchases but do not pay dividends at time $t$, and zero otherwise. The data of share repurchases is taken from Compustat. We observe, in Model (6), banks spend a lower fraction of income on share repurchases (REPUR). However, in Model (7), when we use DUM_REPUR, the

\footnotetext{
5 Stephens and Weisbach (1998) find that share repurchases are negatively associated with prior stock performance since firms increase repurchases when firms are under-evaluated. However, Kane and Susmel (1999), Bonaimé (2012) document positive market reactions on repurchases.
} 
coefficient on DTL is not significant, suggesting that banks are not less likely to repurchase stock as there are more fixed costs. When we focus only to banks that do repurchase but not pay dividends (DUM_REPUR_NODIV) in Model (8), the coefficient is positive and significant.

\subsection{Alternative Measures of DTL}

In this section, we use alternative proxies of DTL, and show the results in Table 5, Panel B, Panel B. One may argue the choice of window (12 quarters) to estimate DTL is arbitrary, we still find similar results with alternative window (20 quarters). Additionally, we use the approach of O'Brien and Vanderheiden (1987) to compute DTL_TRANS, and the results remain unchanged.

\section{Discussion}

So far, we establish that DTL is negatively correlated with the decision to pay and the amount of the payout. Specifically, the result in Table 6 indicates that one standard deviation increase of DTL leads to a $2.5 \%$ decrease in the probability of paying dividends (Model (1)), and to a $4.1 \%$ decrease in the amount of dividends (Model (5)). ${ }^{6}$ These findings are consistent with our hypothesis under different tests.

However, one could suggest that the lower the propensity to pay and the amount of payout in high DTL banks may be derived from the self-interested managers who do not act in the interests of the shareholders and seek for private benefits of control. Hence, the conservative dividend policy observed in high DTL banks could be not in the purpose of maximizing the shareholder value, but is dedicated to the private benefits of managers.

To identify what is the potential reason, we adopt the established methodology pioneered by Fama and French (1998) which aims to examine the marginal value of dividends. Our intuition is as follows. If the lower amount of dividends observed in banks with high DTL reflect the private benefits of controls of managers, dividend payback should be related to a higher value than those from low DTL banks, since paying back to shareholders reduces the available funds for managers. On the contrary, if it is not derived from the managerial discretion, dividend payback in high DTL banks should be related to a lower value than those from low DTL banks, since paying dividends may involve banks to higher probabilities of financial distress.

Specifically, we estimate the following regression separately for high and low DTL banks using Fama and

\footnotetext{
${ }^{6}$ We use margins command in Stata.
}

MacBeth (1973) methodology:

$$
\begin{aligned}
& D M V_{i t}=\alpha+D I V_{i t}+\Delta D I V_{i t}+\Delta F_{-} D I V_{i t} \\
& +E_{A R N I N G S_{i t}}+\triangle E A R N I N G S_{i t} \\
& +\Delta F_{-} E A R N I N G S_{i t}+\triangle A S S E T S_{i t} \\
& +\triangle F_{-} A S S E T S_{i t}+L_{O A N S} \\
& +\triangle L O A N S_{i t}+\Delta F_{-} L O A N S_{i t} \\
& + \text { CAPITAL }_{i t}+\triangle \overline{C A P I T A L}_{i t} \\
& +\Delta F_{-} C A P I T A L_{i t}+\Delta F_{-} D M V_{i t} \\
& +\varepsilon_{i t}
\end{aligned}
$$

\begin{tabular}{|c|c|c|}
\hline & \multicolumn{2}{|c|}{ Dependent Variable $=$ DMV } \\
\hline & LOW DTL & HIGH DTL \\
\hline & (1) & (2) \\
\hline \multirow[t]{2}{*}{ DIV } & $43.126^{* * *}$ & $30.721 * * *$ \\
\hline & $(7.857)$ & $(6.522)$ \\
\hline \multirow[t]{2}{*}{$\Delta \mathrm{DIV}$} & -21.203 & 5.324 \\
\hline & (19.368) & $(12.436)$ \\
\hline \multirow[t]{2}{*}{$\Delta$ F_DIV } & -47.237 & $23.591 *$ \\
\hline & $(42.296)$ & $(12.744)$ \\
\hline \multirow[t]{2}{*}{ EARNINGS } & $15.345^{* * *}$ & $11.636^{* * *}$ \\
\hline & $(3.235)$ & $(2.510)$ \\
\hline \multirow[t]{2}{*}{$\triangle$ EARNINGS } & 0.228 & -1.476 \\
\hline & $(3.797)$ & $(1.198)$ \\
\hline \multirow[t]{2}{*}{$\Delta$ F_EARNINGS } & 1.025 & $3.930 * *$ \\
\hline & $(3.644)$ & $(1.803)$ \\
\hline \multirow[t]{2}{*}{$\triangle$ ASSETS } & -0.081 & 0.032 \\
\hline & $(0.095)$ & $(0.044)$ \\
\hline \multirow[t]{2}{*}{$\Delta \mathrm{F} \_$ASSETS } & -0.055 & 0.054 \\
\hline & $(0.102)$ & $(0.056)$ \\
\hline \multirow[t]{2}{*}{ LOANS } & $-0.087 * * *$ & $-0.057 * * *$ \\
\hline & $(0.018)$ & $(0.020)$ \\
\hline \multirow[t]{2}{*}{$\Delta$ LOANS } & $0.446 * * *$ & -0.013 \\
\hline & $(0.159)$ & $(0.074)$ \\
\hline \multirow[t]{2}{*}{$\Delta \mathrm{F} \_$LOANS } & $0.258^{*}$ & 0.045 \\
\hline & $(0.143)$ & $(0.094)$ \\
\hline \multirow[t]{2}{*}{ CAPITAL } & $-0.373^{*}$ & $-0.281 * * *$ \\
\hline & $(0.185)$ & $(0.089)$ \\
\hline \multirow[t]{2}{*}{$\triangle \mathrm{CAPITAL}$} & 0.620 & 1.461 \\
\hline & $(0.856)$ & $(1.152)$ \\
\hline \multirow[t]{2}{*}{$\Delta \mathrm{F} \_$CAPITAL } & $1.693 *$ & $1.009 *$ \\
\hline & $(0.995)$ & $(0.550)$ \\
\hline \multirow[t]{2}{*}{$\Delta \mathrm{F} \_\mathrm{DMV}$} & $-0.371 * *$ & $-0.457 * *$ \\
\hline & $(0.170)$ & $(0.182)$ \\
\hline \multirow{2}{*}{ Constant } & $0.026^{*}$ & 0.018 \\
\hline & $(0.013)$ & $(0.011)$ \\
\hline Observations & 1,085 & 1,250 \\
\hline Pseudo R2 & 0.851 & 0.792 \\
\hline
\end{tabular}

Table 6: How does DTL affect bank dividend policy?

Panel A reports regression the results of regressing $D M V$ on different characteristics of banks based on Fama and French (1998). We estimate regressions using the method of Fama and MacBeth (1973). $X$ is the level of variable $X$ in time $t$ scaled by the level of assets in time $t . \Delta X$ is the change in the level of $X$ from $t-1$ to $t$, scaled by assets in time $t . \Delta F_{-} X$ is the change in the level of $X$ from $t+1$ to $t$, scaled by assets in time $t$. All financial variables are winsorized at $1 \%$ level on top and bottom of the distribution. $* * *, * * *$ indicate significance at the $1 \%, 5 \%$, and $10 \%$ level respectively. Numbers in parentheses are t-statistics. 
where DMV is the difference between the total market value of a banks and the book value of its assets. $\Delta \mathrm{X}$ is the change in variable $\mathrm{X}$ from time $\mathrm{t}$ to $\mathrm{t}-1$ whereas $\Delta \mathrm{F}$ X $\mathrm{X}$ if the change in variable $X$ from time $t+1$ to $t$. DIV is the amount of dividends; EARNINGS is the income before taxes and provisions; ASSETS is the book value of assets; CAPITAL is the equity capital. All (dependent and independent) variables are scaled to the book value of assets. Hence, the estimated coefficients are interpreted as the dollar change in DMV associated with one dollar increase in the corresponding variable.

The results are shown in Table (6). An additional dollar of current dividend (DIV) is associated with an increase of $\$ 43$ and $\$ 30$ of additional DMV in low and high DTL banks, respectively. And the difference in these extra dollars of DMV between high and low DTL banks is significantly different to zero. The coefficients on $\triangle \mathrm{DIV}$ and $\Delta \mathrm{F}$ _DIV are however not significant, except for the coefficient on $\Delta \mathrm{F}_{-}$DIV for high DTL banks. These results suggest that the conservatism in dividend policy in high DTL banks is not due to the managerial self-interest

\section{Conclusions}

Our study aims to investigate the impacts of the cost structure to the bank dividend policy. We focus on banks with a relatively high fixed-to-variables costs, which are considered as banks with high degree of total leverage. The empirical evidence suggests that banks with high degree of total leverage are less likely to pay dividends to compared with other banks, and those banks spend a lower fraction of income to pay back to shareholders. We provide a battery of sensitivity tests, and find similar results. We further demonstrate that the conservatism in dividend policy in high DTL banks is not due to the managerial self-interest.

\section{References}

Abreu, J. F., \& Gulamhussen, M. A. (2013). Dividend payouts: Evidence from U.S. bank holding companies in the context of the financial crisis. Journal of Corporate Finance, 22, 54-65. https://doi.org/10.1016/j.jcorpfin.2013.04.001

Acharya, V. V., Le, H., \& Shin, H. S. (2016). Bank Capital and Dividend Externalities. The Review of Financial Studies, 30(3), 988-1018. https://doi.org/10.1093/rfs/hhw096.

Allen, F., \& Michaely, R. (2003). Payout Policy. In G. M. Constantinides, M. Harris, \& R. M. Stulz (eds.), Handbook of the Economics of Finance (pp. 337-429). Amsterdam, the Netherlands: North Holland. Retrieved from https://EconPapers.repec.org/RePEc:eee:finchp:107

Berger, A. N., \& Bouwman, C. H. S. (2013). How does capital affect bank performance during financial crises? Journal of Financial Economics, 109(1), 146-176. https://doi.org/10.1016/j.jfineco.2013.02.008

Berger, A. N., Ghoul, S. E., Guedhami, O., \& Roman, R. A. (2016). Internationalization and bank risk. Management Science, 63(7), 2049-2395.

https://doi.org/10.1287/mnsc.2016.2422

Bessler, W., \& Nohel, T. (1996). The stock-market reaction to dividend cuts and omissions by commercial banks. Journal of Banking \& Finance, 20(9), 1485-1508. https://doi.org/10.1016/S0378-4266(96)00004-0

Bessler, W., \& Nohel, T. (2000). Asymmetric information, dividend reductions, and contagion effects in bank stock returns. Journal of Banking \& Finance, 24(11), 18311848. http://dx.doi.org/10.2139/ssrn.236034

Bonaimé, A. A. (2012). Repurchases, reputation, and returns. Journal of Financial and Quantitative Analysis, 47(2), 469-491. https://doi.org/10.1017/S0022109012000087

Committee Basel. (2010). Basel III: A global regulatory framework for more resilient banks and banking systems. Basel Committee on Banking Supervision. Retrieved November 20, 2019, from https://www.bis.org/publ/bcbs189.htm

DeYoung, R., \& Roland, K. P. (2001). Product Mix and Earnings Volatility at Commercial Banks: Evidence from a Degree of Total Leverage Model. Journal of Financial Intermediation, 10(1), 54-84. https://doi.org/10.1006/jfin.2000.0305

Easterbrook, F. H. (1984). Two Agency-Cost Explanations of Dividends. The American Economic Review, 74, 650-659.

Fama, E. F., \& French, K. R. (1998). Taxes, Financing Decisions, and Firm Value. Journal of Finance 53(3), 819-843. https://doi.org/10.1111/0022-1082.00036

Fama, E. F., \& French, K. R. (2001). Disappearing dividends: changing firm characteristics or lower propensity to pay? Journal of Financial Economics, 60(1), 3-43. https://doi.org/10.1016/S0304-405X(01)00038-1

Fama, E. F., \& MacBeth, J. D. (1973). Risk, Return, and Equilibrium: Empirical Tests. Journal of Political Economy, 81, 607-636.

Farre-Mensa, J., Michaely, R., \& Schmalz, M. (2014). Payout Policy. Annual Review of Financial Economics, 6, 75-134. https://doi.org/10.1146/annurev-financial110613-034259

Floyd, E., Li, N., \& Skinner, D. J. (2015). Payout policy through the financial crisis: The growth of repurchases and the resilience of dividends. Journal of Financial 
Economics, 118(2), 299-316.

https://doi.org/10.1016/j.jfineco.2015.08.002

FRB. (2016). Comprehensive Capital Analysis and Review 2016: Summary Instructions and Guidance Introduction. Washington, DC: Board of Governors of the Federal Reserve System.

Retrieved November 20, 2019, from https://www.federalreserve.gov/bankinforeg/stresstests/CCAR/pdfs/bcreg20160128a1.pdf

García-Feijóo, L., \& Jorgensen, R. D. (2010). Can Operating Leverage $\mathrm{Be}$ the Cause of the Value Premium? Financial Management, 39(3), 1127-1154. https://doi.org/10.1111/j.1755-053X.2010.01106.x

Grullon, G., \& Michaely, R. (2002). Dividends, Share Repurchases, and the Substitution Hypothesis. The Journal of Finance, 57(4), 1649-1684. https://doi.org/10.1111/1540-6261.00474

Guay, W., \& Harford, J. (2000). The cash-flow permanence and information content of dividend increases versus repurchases. Journal of Financial Economics, 57(3), 385-415. https://doi.org/10.1016/S0304-405X(00)00062-3

Healy, P. M., \& Palepu, K. R. (1988). Earnings information conveyed by dividend initiations and omissions. Journal of Financial Economics, 21, 149-175.

Hirtle, B. (2004). Stock repurchases and bank holding company performance. Journal of Financial Intermediation, 13(1), 28-57. https://doi.org/10.1016/S1042-9573(03)00028-7

Jagannathan, M., Stephens, C. P., \& Weisbach, M. S. (2000). Financial flexibility and the choice between dividends and stock repurchases. Journal of Financial Economics, 57(3), 355-384.

Jensen, M. C. (1986). Agency costs of free cash flow, corporate finance, and takeovers. The American Economic Review, 76(2), 323-329.

Kane, S., \& Susmel, R. (1999). Regime-switching event studies: An application to commercial bank stock repurchases. Research in Finance, 17, 81-102. [Please provide correct information]

Kulchania, M. (2016). Cost Structure and Payout Policy. Financial Management, 45(4), 981-1009. https://doi.org/10.1111/fima.12133

La Porta, R., Lopez-de-Silanes, F., Shleifer, A., \& Vishny, R. W. (2000). Agency problems and dividend policies around the world. The Journal of Finance, 55(1), 1-33. https://doi.org/10.1111/0022-1082.00199
[Please provide a citation in text, otherwise delete it]

Lemmon, M. L., Roberts, M. R., \& Zender, J. F. (2008). Back to the beginning: persistence and the cross-section of corporate capital structure. The Journal of Finance, 63(4), 1575-1608.

https://doi.org/10.1111/j.1540-6261.2008.01369.x

Mandelker, G. N., \& Rhee, S. G. (1984). The Impact of the Degrees of Operating and Financial Leverage on Systematic Risk of Common Stock. The Journal of Financial and Quantitative Analysis, 19(1), 45-57. https://doi.org/10.2307/2331000

Miller, M. H., \& Modigliani, F. (1961). Dividend policy, growth, and the valuation of shares. Journal of Business, 34(4), 411-433.

Myers, S. C. (2000). Outside equity. Journal of Finance, 55(3), 1005-1037. https://doi.org/10.1111/0022-1082.00239

O’Brien, T. J., \& Vanderheiden, P. A. (1987). Empirical Measurement of Operating Leverage for Growing Firms. Financial Management, 16(2), 45-53. doi: $10.2307 / 3666003$

Rozeff, M. S. (1982). Growth, beta and agency costs as determinants of dividend payout ratios. Journal of Financial Research, 5(3), 249-259. https://doi.org/10.1111/j.1475-6803.1982.tb00299.x

Skinner, D. J. (2008). The evolving relation between earnings, dividends, and stock repurchases. Journal of Financial Economics, 87(3), 582-609. https://doi.org/10.1016/j.jfineco.2007.05.003

Stephens, C. P., \& Weisbach, M. S. (1998). Actual share reacquisitions in open-market repurchase programs. The Journal of Finance, 53(1), 313-333. https://doi.org/10.1111/0022-1082.115194

Tran, D. V., \& Ashraf, B. N. (2018). Dividend policy and bank opacity. International Journal of Finance \& Economics, 23(2), 186-204. https://doi.org/10.1002/ijfe.1611

Tran, D. V., Hassan, M. K., \& Houston, R. (2019). Activity strategies, information asymmetry, and bank opacity. Economic Modelling, 83, 160-172. https://doi.org/10.1016/j.econmod.2019.02.008

Tran, D. V., Hassan, M. K., \& Houston, R. (2019). How does listing status affect bank risk? The effects of crisis, market discipline and regulatory pressure on listed and unlisted BHCs. The North American Journal of Economics and Finance, 49, 85-103. https://doi.org/10.1016/j.najef.2019.03.007 


\section{Appendix}

\section{A. Construction of DeYoung and Roland (2001)'s DTL Measure}

To construct DTL, we follow DeYoung and Roland (2001) by using a two-step statistical approach. The first stage consists to correct the time trend in profits and revenues since the trend is dominant over the residual variation.

$$
\begin{aligned}
& \pi_{i t}=\pi_{i 0}+\gamma_{i \pi 1} t+\gamma_{i \pi 2} t^{2}+\gamma_{i \pi 3} t^{3}+\delta_{i 1} q 1 \\
& +\delta_{\mathrm{i} 2} \mathrm{q} 2+\delta_{\mathrm{i} 3} \mathrm{q} 3+\mu(\pi)_{\mathrm{it}} \\
& r_{i t}=r_{i 0}+\gamma_{i r 1} t+\gamma_{i r 2} t^{2}+\gamma_{i r 3} t^{3}+\delta_{i 1} q 1 \\
& +\delta_{\mathrm{i} 2} \mathrm{q} 2+\delta_{\mathrm{i} 3} \mathrm{q} 3+\mu(\mathrm{r})_{\mathrm{it}}
\end{aligned}
$$

where $\pi, r$ are bank' earnings and revenues. $\pi_{\mathrm{i} 0}$ and $r_{\mathrm{i} 0}$ are earnings and revenues at initial quarter.

In the second stage, the disturbance terms $\mu(\pi)_{\text {it }}$ and $\mu(r)_{\text {it }}$ are used to estimate $D T L$.

$\mu(\pi)_{i t}=\alpha_{i}+\beta_{i} \mu(r)_{i t}+\varepsilon_{i t}$

We estimate (A1), (A2) and (A3) for each banks with a window of 12 quarters. Finally, to be in line with DeYoung and Roland (2001), we transform $\beta$ coefficient into an elasticity measure

$\mathrm{DTL}_{\mathrm{it}}=\beta_{\mathrm{it}} \frac{\overline{\mathrm{r}_{\mathrm{it}}}}{\overline{\pi_{1 \mathrm{t}}}}$

where $\overline{r_{1 t}}$, and $\overline{\pi_{1 t}}$ are the average of revenues and profits of bank i over 12 quarters. For this study, we exclude all negative $D T L$ since negative $D T L$ banks are banks that work under the break-even point, and may have different behaviors than other banks.

\section{Appendix B.}

Construction of García-Feijóo and Jorgensen (2010)'s DTL Measure

For robustness check, we construct DTL following García-Feijóo and Jorgensen (2010) which is closer to the origin approach proposed by Mandelker and Rhee (1984), O’Brien and Vanderheiden (1987).

$\ln \pi_{i t}=\ln \pi_{i 0}+\gamma_{i \pi 1} t+\mu(\pi)_{i t}$

$\ln r_{i t}=\ln r_{i 0}+\gamma_{\text {ir } 1} t+\mu(r)_{i t}$

Since $\pi_{i t}$ could be negative, we use the transformation: $\ln (1+\pi)$ if $\pi$ is positive, and $-\ln (1-\pi)$ if $\pi$ is negative. The following step is similar to (A3) and (A4). 